\title{
The KT Jeang Retrovirology prize 2018: Eric Freed
}

\author{
Retrovirology Editorial ${ }^{*}$
}

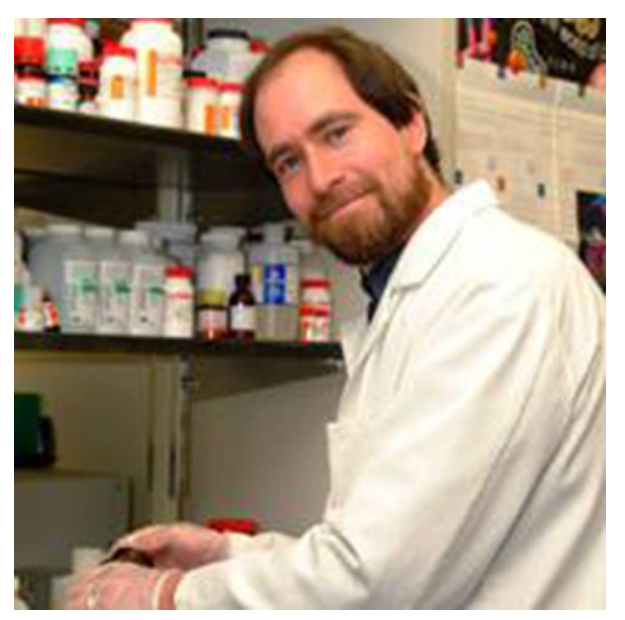

Fig. 1 Eric Freed

Dr. Eric Freed did his undergraduate studies at Penn State University, where he had the good fortune of becoming involved in research on the $\operatorname{src}$ oncogene in the laboratory of Dr. David Shalloway [1]. This early research experience sparked a long-standing interest in viruses-and, more specifically_retroviruses (Fig. 1).

In 1985, Freed began his Ph.D. studies at the University of Wisconsin, Madison, in the laboratory of Dr. Rex Risser. Although research in the Risser laboratory was primarily focused on cell transformation by Abelson murine leukemia virus (MLV), Freed decided from the outset of his Ph.D. research to pursue a different direction-studying membrane fusion mediated by retroviral envelope

*Correspondence: editorial@retrovirology.com London, UK
(Env) glycoproteins. He began by defining the sequence required for MLV Env precursor processing, which he showed was essential for Env-mediated fusion and viral infectivity [2]. In 1988, Freed's research began to shift from MLV to HIV-1. Freed noted sequence similarities between the MLV and HIV-1 Env glycoprotein precursor cleavage sites, an observation that led him to characterize the HIV-1 Env cleavage sequence [3], and to define the function of the hydrophobic sequence-the gp41 fusion peptide-located immediately downstream of the Env precursor cleavage site [4]. This early work also identified the V3 loop of HIV-1 gp120 (known at that time as the principal neutralizing determinant) as a region of Env critical for membrane fusion [5]. The observation that a gp41 fusion peptide mutation elicited a strong dominantnegative effect on membrane fusion led Freed to speculate that Env likely functions as a multimer [6]. Tragically, Freed's mentor Rex Risser passed away in 1990, at age 42, just months before Dr. Freed's Ph.D. thesis defense. Dr. Freed finished his Ph.D. research, and did a 1-year postdoctoral fellowship, under the mentorship of Nobel laureate Dr. Howard Temin; Freed's work during this time continued to focus on elucidating the function of HIV-1 and HIV-2 Env glycoproteins [7, 8].

In 1992, Freed moved to the NIAID/NIH in Bethesda, Maryland to continue postdoctoral research with Dr. Malcolm Martin. Although Freed maintained his focus on HIV-1, his interests shifted to Gag and virus assembly. During this time, much of his research centered on the matrix (MA) domain of Gag and its role in Gag trafficking, membrane binding, Env incorporation, and virus entry [9-16]. Using oligonucleotide site-directed mutagenesis with M13-derived phage vectors, Freed introduced a large number of mutations into the MA domain of HIV-1 Gag. Two classes of mutations turned out to be particularly interesting: those that blocked Env incorporation into virions, and those, located in a highly 
basic region of MA, that retargeted virus assembly from the plasma membrane to an intracellular compartment [9-11, 14-16]. His research also addressed the then-controversial hypothesis that MA regulates HIV-1 nuclear import at an early step post-infection [17-19].

In 1995, Freed published a study demonstrating that the virus budding activity of the p6 domain of Gag, originally described by Göttlinger et al. [20], maps to a Pro-Thr-Ala-Pro (PTAP) motif [21]. Within a severalmonth period from late 2001 to early 2002, four groups (those of Carol Carter, Wesley Sundquist, Paul Bieniasz, and Freed) showed that the PTAP motif of p6 promotes virus budding by binding directly to the ESCRT-I component Tsg101 [22-25]. It soon became clear that PTAP motifs play central roles in protein-protein interactions required for ESCRT activity (e.g., in multivesicular body biogenesis and cytokinesis), adding to the long list of instances in which research in virology has provided fundamental insights into our understanding of molecular and cell biology.

Freed became a tenure-track investigator in 1997 and received tenure from the NIAID and NIH 5 years later (2002). The following year, in 2003, Freed moved his laboratory to the HIV Drug Resistance Program (HIV DRP) at the National Cancer Institute in Frederick, Maryland. The HIV DRP had been founded by John Coffin several years earlier.

Freed's research in the early 2000s continued to address host cell determinants involved in virus assembly and Env incorporation into virus particles. Freed's postdoctoral fellow Akira Ono demonstrated that HIV-1 assembly takes place in lipid rafts at the plasma membrane [26], and that targeting of Gag to the plasma membrane relies on the lipid phosphatidylinositol-4,5-bisphosphate $\left[\mathrm{PI}(4,5) \mathrm{P}_{2}\right][27]$. Ono and Freed showed that depletion of $\mathrm{PI}(4,5) \mathrm{P}_{2}$ from the plasma membrane of virus-producing cells produced the same phenotype that Freed had earlier described for MA basic residue mutations-the retargeting of Gag to an intracellular compartment-establishing $\mathrm{PI}(4,5) \mathrm{P}_{2}$ as a key cellular determinant in the regulation of Gag trafficking to the plasma membrane. Others, most notably Jamil Saad and Michael Summers, subsequently showed that the basic region of MA interacts directly with $\operatorname{PI}(4,5) \mathrm{P}_{2}[28]$.

A theme in Freed's research for many years has been the interplay between the gp41 cytoplasmic tail and the MA domain of Gag. His early work had shown that single amino acid mutations in MA block Env incorporation, and that this block can be overcome by deleting the gp 41 cytoplasmic tail [9]. Freed's postdoctoral fellow Tsutomu Murakami showed that the long cytoplasmic tail of gp41 is required for Env incorporation and virus replication in physiologically relevant cell types (e.g., most $\mathrm{T}$ cell lines and primary $\mathrm{T}$ cells) but is not required in adherent cell lines like 293T and HeLa, or in the MT-4 T-cell line [9]. These results suggested that cellular factor(s) promote Env incorporation in a gp41 cytoplasmic tail-dependent manner, a hypothesis that continues to be an active area of investigation. Murakami also showed that defects in Env incorporation and virus replication induced by a small deletion in the gp41 cytoplasmic tail could be rescued by a point mutation in MA, consistent with crosstalk between MA and gp41 [29]. In vitro studies by other groups [30-32] had shown that MA is capable of forming trimers; recently, Freed's postdoctoral fellow Philip Tedbury showed that a mutation at the putative trimer interface can globally rescue Env incorporation defects [33] and provided direct evidence, by using a cross-linking approach, that MA is indeed trimeric in HIV-1 virions and that MA trimerization is critical to Env incorporation [34]. Work during this period also focused on host cell proteins and pathways involved in HIV-1 Gag targeting and virus budding [35-40].

An additional focus of Freed's research since the early 2000s has been the development of HIV-1 maturation inhibitors [41-45]. In collaboration with researchers at Panacos Pharmaceuticals, including Feng Li and Carl Wild, Freed's group showed in 2003 that the first-inclass maturation inhibitor dimethylsuccinyl betulinic acid (PA-457 or bevirimat) blocks virus maturation by preventing the processing of the capsid-spacer peptide 1 (CA-SP1) Gag cleavage intermediate to mature CA [41], an observation made independently shortly thereafter by Chris Aiken's laboratory [46]. Bevirimat displayed antiviral activity in phase IIb clinical trials [47]; although its activity was compromised by polymorphisms in SP1 [43, 48], this work established proof-of-concept that using a small molecule to block an individual Gag cleavage site can be an effective antiviral strategy in humans. Significant insights into the maturation inhibitor target and mechanism of action were gained from Freed's work on a structurally distinct maturation inhibitor, known as PF-46396, originally reported by Pfizer [44]. In collaboration with DFH Pharma (headed by Carl Wild) and Hetero Drugs, recent work on maturation inhibitors in the Freed lab has been focused on developing highly potent and broadly active maturation inhibitors that overcome the loss of activity imposed by sequence polymorphisms in SP1. Parallel basic research in Freed's lab, greatly assisted by cryo-electron tomography and solid-state NMR with collaborators Alasdair Steven and Tatyana Polenova [49-52], and independently by other structural biologists (e.g., Owen Pornillos and John Briggs [53, 54]), has suggested that maturation inhibitors block CA-SP1 processing by stabilizing a highly dynamic, six-helix bundle that forms at the CA-SP1 junction. This work, which 
relied heavily on the identification and characterization of compound-resistant viruses, is intellectually satisfying in that it illustrates how translational studies on antiviral drug candidates can provide insights into basic virology and structural biology. The maturation inhibitor research in the Freed lab has been carried out by a series of talented postdoctoral fellows (Ritu Gaur, Catherine Adamson, Kayoko Waki, Emiko Urano, and Mariia Novikova), a technician (Sherimay Ablan), and postbaccalaureate interns (Rebecca Mandt, Nishani Kuruppu, Justin Kaplan, Phuong Pham, and Hannah Carter). Other projects currently ongoing in the Freed laboratory involve identifying host cell machinery involved in Env trafficking and incorporation (postdoc Melissa Fernandez); late-acting cellular inhibitory factors that target virus assembly and Env biogenesis, stability and trafficking (postdocs James Kirui and Cheng Man Lun and staff scientist Abdul Waheed); and characterizing a panel of Env mutants that confer resistance to antiretrovirals (postdoc Rachel Van Duyne).

Research in the Freed laboratory has benefited greatly from a number of productive and rewarding collaborations with investigators both within and outside of the NIH, including Schuyler van Engelenburg, Jennifer Lippincott-Schwartz, Juan Bonifacino, James Hurley, Michael Summers, Judith Levin, Eric Barklis, Asim Debnath, Simon Cocklin, Shan-Lu Liu, and Sriram Subramaniam, to name a few [36, 39, 55-74].

In 2014, Freed became Deputy Director of the HIV DRP (under then-Director Stephen Hughes) and in 2015 became Director of the HIV DRP, which was renamed the HIV Dynamics and Replication Program. Freed enjoys close scientific interactions with the other DRP PIs-Stephen Hughes, Alan Rein, Vinay Pathak, Wei-Shau Hu, Frank Maldarelli, Mary Kierney, and Alex Comptonand with DRP-associated investigators John Coffin and John Mellors.

Freed has long been an advocate for virology research and has worked to promote interactions among virologists. Since its launch in 2009, he has served as Editor-inChief of the open-access journal Viruses. He also serves as an Editor for Journal of Molecular Biology and is on the editorial boards of several virology journals, including Journal of Virology and Retrovirology. Starting in 2018, he is serving as an Associate Editor for Fields Virology. Freed has been an organizer for a number of international virology conferences, including the Cold Spring Harbor Retroviruses Meeting (2004); American Society for Cell Biology Conference on the Cell Biology of HIV-1 and Other Retroviruses (2006); the Keystone Meeting "Frontiers in HIV Pathogenesis, Therapy and Eradication" (2012); the Keystone Meeting "The Ins and Outs of Viral Infection: Entry, Assembly, Exit and Spread" (2014); two conferences sponsored by Viruses: "At the Forefront of Virus-Host Interactions (Basel, Switzerland, 2016) and "Breakthroughs in Viral Replication" (Barcelona, Spain, 2018); and the International Workshop of the Structure and Function of the gp41 Cytoplasmic Tail (National Cancer Institute, 2018). Freed is Co-Chair of the NIH Virology Interest Group and Co-Director of the University of Maryland Virology Program. In addition to ad hoc service on many national and international study sections and grant review panels, he was a member of the NIH AIDS Discovery and Development of Therapeutics (ADDT) Study Section from 2012 to 2017 and served as ADDT Chair from 2015 to 2017. The recognition of which Freed is perhaps most proud is an NCI Mentor of Merit Award for excellence in mentoring.

When not working, Freed enjoys running, hiking, skiing, biking, backpacking, fly fishing, and music, and spending time with his family.

\section{Publisher's Note}

Springer Nature remains neutral with regard to jurisdictional claims in published maps and institutional affiliations.

Received: 26 June 2018 Accepted: 26 June 2018

Published online: 02 July 2018

\section{References}

1. Shalloway D, Johnson PJ, Freed EO, Coulter D, Flood WA Jr. Transformation of NIH $3 \mathrm{~T} 3$ cells by cotransfection with C-src and nuclear oncogenes. Mol Cell Biol. 1987;7(10):3582-90.

2. Freed EO, Risser R. The role of envelope glycoprotein processing in murine leukemia virus infection. J Virol. 1987;61(9):2852-6.

3. Freed EO, Myers DJ, Risser R. Mutational analysis of the cleavage sequence of the human immunodeficiency virus type 1 envelope glycoprotein precursor gp160. J Virol. 1989;63(11):4670-5.

4. Freed EO, Myers DJ, Risser R. Characterization of the fusion domain of the human immunodeficiency virus type 1 envelope glycoprotein gp41. Proc Natl Acad Sci USA. 1990;87(12):4650-4.

5. Freed EO, Myers DJ, Risser R. Identification of the principal neutralizing determinant of human immunodeficiency virus type 1 as a fusion domain. J Virol. 1991;65(1):190-4.

6. Freed EO, Delwart EL, Buchschacher GL Jr, Panganiban AT. A mutation in the human immunodeficiency virus type 1 transmembrane glycoprotein gp41 dominantly interferes with fusion and infectivity. Proc Natl Acad Sci USA. 1992;89(1):70-4.

7. Freed EO, Martin MA. Evidence for a functional interaction between the V1/N2 and C4 domains of human immunodeficiency virus type 1 envelope glycoprotein gp120. J Virol. 1994;68(4):2503-12.

8. Freed EO, Myers DJ. Identification and characterization of fusion and processing domains of the human immunodeficiency virus type 2 envelope glycoprotein. J Virol. 1992;66(9):5472-8.

9. Freed EO, Martin MA. Virion incorporation of envelope glycoproteins with long but not short cytoplasmic tails is blocked by specific, single amino acid substitutions in the human immunodeficiency virus type 1 matrix. J Virol. 1995;69(3):1984-9.

10. Freed EO, Martin MA. Domains of the human immunodeficiency virus type 1 matrix and gp41 cytoplasmic tail required for envelope incorporation into virions. J Virol. 1996;70(1):341-51.

11. Freed EO, Orenstein JM, Buckler-White AJ, Martin MA. Single amino acid changes in the human immunodeficiency virus type 1 matrix protein block virus particle production. J Virol. 1994;68(8):5311-20. 
12. Kiernan RE, Ono A, Englund G, Freed EO. Role of matrix in an early postentry step in the human immunodeficiency virus type 1 life cycle. J Virol. 1998;72(5):4116-26

13. Kiernan RE, Ono A, Freed EO. Reversion of a human immunodeficiency virus type 1 matrix mutation affecting Gag membrane binding, endogenous reverse transcriptase activity, and virus infectivity. J Virol. 1999;73(6):4728-37.

14. Ono A, Freed EO. Binding of human immunodeficiency virus type 1 Gag to membrane: role of the matrix amino terminus. J Virol. 1999;73(5):4136-44.

15. Ono A, Huang M, Freed EO. Characterization of human immunodeficiency virus type 1 matrix revertants: effects on virus assembly, Gag processing, and Env incorporation into virions. J Virol. 1997;71(6):4409-18.

16. Ono A, Orenstein JM, Freed EO. Role of the Gag matrix domain in targeting human immunodeficiency virus type 1 assembly. J Virol. 2000;74(6):2855-66

17. Freed EO, Englund G, Maldarelli F, Martin MA. Phosphorylation of residue 131 of HIV-1 matrix is not required for macrophage infection. Cell. 1997;88(2):171-3.

18. Freed EO, Englund G, Martin MA. Role of the basic domain of human immunodeficiency virus type 1 matrix in macrophage infection. J Virol. 1995;69(6):3949-54.

19. Freed EO, Martin MA. HIV-1 infection of non-dividing cells. Nature. 1994;369(6476):107-8.

20. Gottlinger HG, Dorfman T, Sodroski JG, Haseltine WA. Effect of mutations affecting the $\mathrm{p} 6 \mathrm{gag}$ protein on human immunodeficiency virus particle release. Proc Natl Acad Sci USA. 1991;88(8):3195-9.

21. Huang M, Orenstein JM, Martin MA, Freed EO. p6Gag is required for particle production from full-length human immunodeficiency virus type 1 molecular clones expressing protease. J Virol. 1995;69(11):6810-8.

22. Garrus JE, von Schwedler UK, Pornillos OW, Morham SG, Zavitz KH, Wang HE, Wettstein DA, Stray KM, Cote M, Rich RL, et al. Tsg101 and the vacuolar protein sorting pathway are essential for HIV-1 budding. Cell. 2001;107(1):55-65.

23. Martin-Serrano J, Zang T, Bieniasz PD. HIV-1 and Ebola virus encode small peptide motifs that recruit Tsg101 to sites of particle assembly to facilitate egress. Nat Med. 2001;7(12):1313-9.

24. VerPlank L, Bouamr F, LaGrassa TJ, Agresta B, Kikonyogo A, Leis J, Carter CA. Tsg101, a homologue of ubiquitin-conjugating (E2) enzymes, binds the L domain in HIV type 1 Pr55(Gag). Proc Natl Acad Sci USA. 2001;98(14):7724-9.

25. Demirov DG, Ono A, Orenstein JM, Freed EO. Overexpression of the $\mathrm{N}$-terminal domain of TSG101 inhibits HIV-1 budding by blocking late domain function. Proc Natl Acad Sci USA. 2002;99(2):955-60.

26. Ono A, Freed EO. Plasma membrane rafts play a critical role in HIV-1 assembly and release. Proc Natl Acad Sci USA. 2001;98(24):13925-30.

27. Ono A, Ablan SD, Lockett SJ, Nagashima K, Freed EO. Phosphatidylinositol $(4,5)$ bisphosphate regulates HIV-1 Gag targeting to the plasma membrane. Proc Natl Acad Sci USA. 2004;101(41):14889-94.

28. Saad JS, Miller J, Tai J, Kim A, Ghanam RH, Summers MF. Structural basis for targeting HIV-1 Gag proteins to the plasma membrane for virus assembly. Proc Natl Acad Sci USA. 2006;103(30):11364-9.

29. Murakami T, Freed EO. Genetic evidence for an interaction between human immunodeficiency virus type 1 matrix and alpha-helix 2 of the gp41 cytoplasmic tail. J Virol. 2000;74(8):3548-54.

30. Hill CP, Worthylake D, Bancroft DP, Christensen AM, Sundquist WI. Crysta structures of the trimeric human immunodeficiency virus type 1 matrix protein: implications for membrane association and assembly. Proc Natl Acad Sci USA. 1996;93(7):3099-104.

31. Alfadhli A, Barklis RL, Barklis E. HIV-1 matrix organizes as a hexamer of trimers on membranes containing phosphatidylinositol-(4,5)-bisphosphate. Virology. 2009;387(2):466-72

32. Rao Z, Belyaev AS, Fry E, Roy P, Jones IM, Stuart DI. Crystal structure of SIV matrix antigen and implications for virus assembly. Nature. 1995;378(6558):743-7.

33. Tedbury PR, Ablan SD, Freed EO. Global rescue of defects in HIV-1 envelope glycoprotein incorporation: implications for matrix structure. PLOS Pathog. 2013;9(11):e1003739.

34. Tedbury PR, Novikova M, Ablan SD, Freed EO. Biochemical evidence of a role for matrix trimerization in HIV-1 envelope glycoprotein incorporation. Proc Natl Acad Sci USA. 2016;113(2):E182-90.
35. Joshi A, Ablan SD, Soheilian F, Nagashima K, Freed EO. Evidence that productive human immunodeficiency virus type 1 assembly can occur in an intracellular compartment. J Virol. 2009;83(11):5375-87.

36. Joshi A, Garg H, Nagashima K, Bonifacino JS, Freed EO. GGA and Arf proteins modulate retrovirus assembly and release. Mol Cell. 2008;30(2):227-38.

37. Joshi A, Munshi U, Ablan SD, Nagashima K, Freed EO. Functional replacement of a retroviral late domain by ubiquitin fusion. Traffic. 2008;9(11):1972-83.

38. Gousset K, Ablan SD, Coren LV, Ono A, Soheilian F, Nagashima K, Ott DE, Freed EO. Real-time visualization of HIV-1 GAG trafficking in infected macrophages. PLoS Pathog. 2008;4(3):e1000015.

39. Munshi UM, Kim J, Nagashima K, Hurley JH, Freed EO. An Alix fragment potently inhibits HIV-1 budding: characterization of binding to retroviral YPXL late domains. J Biol Chem. 2007;282(6):3847-55.

40. Fujii K, Munshi UM, Ablan SD, Demirov DG, Soheilian F, Nagashima K, Stephen AG, Fisher RJ, Freed EO. Functional role of Alix in HIV-1 replication. Virology. 2009;391(2):284-92.

41. Li F, Goila-Gaur R, Salzwedel K, Kilgore NR, Reddick M, Matallana C, Castillo A, Zoumplis D, Martin DE, Orenstein JM, et al. PA-457: a potent HIV inhibitor that disrupts core condensation by targeting a late step in Gag processing. Proc Natl Acad Sci USA. 2003;100(23):13555-60.

42. Adamson CS, Ablan SD, Boeras I, Goila-Gaur R, Soheilian F, Nagashima K, Li F, Salzwedel K, Sakalian M, Wild CT, et al. In vitro resistance to the human immunodeficiency virus type 1 maturation inhibitor PA-457 (Bevirimat). J Virol. 2006;80(22):10957-71

43. Adamson CS, Sakalian M, Salzwedel K, Freed EO. Polymorphisms in Gag spacer peptide 1 confer varying levels of resistance to the HIV-1 maturation inhibitor bevirimat. Retrovirology. 2010;7:36.

44. Waki K, Durell SR, Soheilian F, Nagashima K, Butler SL, Freed EO. Structural and functional insights into the HIV-1 maturation inhibitor binding pocket. PLoS Pathog. 2012;8(11):e1002997.

45. Urano E, Ablan SD, Mandt R, Pauly GT, Sigano DM, Schneider JP, Martin DE, Nitz TJ, Wild CT, Freed EO. Alkyl amine bevirimat derivatives are potent and broadly active HIV-1 maturation inhibitors. Antimicrob Agents Chemother. 2016;60(1):190-7.

46. Zhou J, Yuan X, Dismuke D, Forshey BM, Lundquist C, Lee KH, Aiken $\mathrm{C}$, Chen $\mathrm{CH}$. Small-molecule inhibition of human immunodeficiency virus type 1 replication by specific targeting of the final step of virion maturation. J Virol. 2004;78(2):922-9.

47. Martin DE, Salzwedel K, Allaway GP. Bevirimat: a novel maturation inhibitor for the treatment of HIV-1 infection. Antivir Chem Chemother. 2008;19(3):107-13.

48. Van Baelen K, Salzwedel K, Rondelez E, Van Eygen V, De Vos S, Verheyen A, Steegen K, Verlinden Y, Allaway GP, Stuyver LJ. Susceptibility of human immunodeficiency virus type 1 to the maturation inhibitor bevirimat is modulated by baseline polymorphisms in Gag spacer peptide 1. Antimicrob Agents Chemother. 2009;53(5):2185-8.

49. Fontana J, Keller PW, Urano E, Ablan SD, Steven AC, Freed EO. Identification of an HIV-1 mutation in spacer peptide 1 that stabilizes the immature CA-SP1 lattice. J Virol. 2016;90(2):972-8.

50. Keller PW, Adamson CS, Heymann JB, Freed EO, Steven AC. HIV-1 maturation inhibitor bevirimat stabilizes the immature Gag lattice. J Virol. 2011;85(4):1420-8.

51. Keller PW, Huang RK, England MR, Waki K, Cheng N, Heymann JB, Craven RC, Freed EO, Steven AC. A two-pronged structural analysis of retroviral maturation indicates that core formation proceeds by a disassembly-reassembly pathway rather than a displacive transition. J Virol. 2013;87(24):13655-64.

52. Wang M, Quinn CM, Perilla JR, Zhang H, Shirra R Jr, Hou G, Byeon IJ, Suiter CL, Ablan S, Urano E, et al. Quenching protein dynamics interferes with HIV capsid maturation. Nat Commun. 2017;8(1):1779.

53. Schur FK, Obr M, Hagen WJ, Wan W, Jakobi AJ, Kirkpatrick JM, Sachse C, Krausslich HG, Briggs JA. An atomic model of HIV-1 capsid-SP1 reveals structures regulating assembly and maturation. Science. 2016:353(6298):506-8.

54. Wagner JM, Zadrozny KK, Chrustowicz J, Purdy MD, Yeager M, GanserPornillos BK, Pornillos O. Crystal structure of an HIV assembly and maturation switch. Elife. 2016;5:e17063.

55. Fujii K, Hurley JH, Freed EO. Beyond Tsg 101: the role of Alix in 'ESCRTing' HIV-1. Nat Rev Microbiol. 2007;5(12):912-6. 
56. Im YJ, Kuo L, Ren X, Burgos PV, Zhao XZ, Liu F, Burke TR Jr, Bonifacino JS, Freed EO, Hurley JH. Crystallographic and functional analysis of the ESCRT-I/HIV-1 Gag PTAP interaction. Structure. 2010;18(11):1536-47.

57. Kim SE, Liu F, Im YJ, Stephen AG, Fivash MJ, Waheed AA, Freed EO, Fisher RJ, Hurley JH, Burke TR Jr. Elucidation of new binding interactions with the tumor susceptibility gene 101 (Tsg101) protein using modified HIV-1 Gag-p6 derived peptide ligands. ACS Med Chem Lett. 2011;2(5):337-41.

58. Lee S, Joshi A, Nagashima K, Freed EO, Hurley JH. Structural basis for viral late-domain binding to Alix. Nat Struct Mol Biol. 2007:14(3):194-9.

59. Buttler CA, Pezeshkian N, Fernandez MV, Aaron J, Norman S, Freed EO, van Engelenburg SB. Single molecule fate of HIV-1 envelope reveals latestage viral lattice incorporation. Nat Commun. 2018;9(1):1861.

60. Chen AK, Sengupta P, Waki K, Van Engelenburg SB, Ochiya T, Ablan SD Freed EO, Lippincott-Schwartz J. MicroRNA binding to the HIV-1 Gag protein inhibits Gag assembly and virus production. Proc Natl Acad Sci USA. 2014;111(26):E2676-83.

61. Lippincott-Schwartz J, Freed EO, van Engelenburg SB. A consensus view of ESCRT-mediated human immunodeficiency virus type 1 abscission. Annu Rev Virol. 2017;4(1):309-25.

62. Van Engelenburg SB, Shtengel G, Sengupta P, Waki K, Jarnik M, Ablan SD, Freed EO, Hess HF, Lippincott-Schwartz J. Distribution of ESCRT machinery at HIV assembly sites reveals virus scaffolding of ESCRT subunits. Science. 2014;343(6171):653-6.

63. Park SY, Waheed AA, Zhang ZR, Freed EO, Bonifacino JS. HIV-1 Vpu accessory protein induces caspase-mediated cleavage of IRF3 transcription factor. J Biol Chem. 2014;289(51):35102-10.

64. Jiang J, Ablan SD, Derebail S, Hercik K, Soheilian F, Thomas JA, Tang S, Hewlett I, Nagashima K, Gorelick RJ, et al. The interdomain linker region of HIV-1 capsid protein is a critical determinant of proper core assembly and stability. Virology. 2011;421(2):253-65.

65. Tang S, Ablan S, Dueck M, Ayala-Lopez W, Soto B, Caplan M, Nagashima K, Hewlett IK, Freed EO, Levin JG. A second-site suppressor significantly improves the defective phenotype imposed by mutation of an aromatic residue in the $\mathrm{N}$-terminal domain of the HIV-1 capsid protein. Virology. 2007;359(1):105-15.
66. Tang S, Murakami T, Agresta BE, Campbell S, Freed EO, Levin JG. Human immunodeficiency virus type $1 \mathrm{~N}$-terminal capsid mutants that exhibit aberrant core morphology and are blocked in initiation of reverse transcription in infected cells. J Virol. 2001;75(19):9357-66.

67. Tang S, Murakami T, Cheng N, Steven AC, Freed EO, Levin JG. Human immunodeficiency virus type $1 \mathrm{~N}$-terminal capsid mutants containing cores with abnormally high levels of capsid protein and virtually no reverse transcriptase. J Virol. 2003;77(23):12592-602.

68. Checkley MA, Luttge BG, Mercredi PY, Kyere SK, Donlan J, Murakami T, Summers MF, Cocklin S, Freed EO. Reevaluation of the requirement for TIP47 in human immunodeficiency virus type 1 envelope glycoprotein incorporation. J Virol. 2013;87(6):3561-70.

69. Alfadhli A, Mack A, Ritchie C, Cylinder I, Harper L, Tedbury PR, Freed EO, Barklis E. Trimer enhancement mutation effects on HIV-1 matrix protein binding activities. J Virol. 2016;90(12):5657-64.

70. Zhang H, Curreli F, Waheed AA, Mercredi PY, Mehta M, Bhargava P, Scacalossi D, Tong $X$, Lee $S$, Cooper A, et al. Dual-acting stapled peptides target both HIV-1 entry and assembly. Retrovirology. 2013;10:136.

71. Zhang H, Curreli F, Zhang X, Bhattacharya S, Waheed AA, Cooper A, Cowburn D, Freed EO, Debnath AK. Antiviral activity of alpha-helical stapled peptides designed from the HIV-1 capsid dimerization domain. Retrovirology. 2011;8:28.

72. Zhang H, Zhao Q, Bhattacharya S, Waheed AA, Tong X, Hong A, Heck S, Curreli F, Goger M, Cowburn D, et al. A cell-penetrating helical peptide as a potential HIV-1 inhibitor. J Mol Biol. 2008;378(3):565-80.

73. Li M, Ablan SD, Miao C, Zheng YM, Fuller MS, Rennert PD, Maury W, Johnson MC, Freed EO, Liu SL. TIM-family proteins inhibit HIV-1 release. Proc Natl Acad Sci USA. 2014;111(35):E3699-707.

74. Bennett AE, Narayan K, Shi D, Hartnell LM, Gousset K, He H, Lowekamp $B C$, Yoo TS, Bliss D, Freed EO, et al. Ion-abrasion scanning electron microscopy reveals surface-connected tubular conduits in HIV-infected macrophages. PLoS Pathog. 2009;5(9):e1000591.
Ready to submit your research? Choose BMC and benefit from:

- fast, convenient online submission

- thorough peer review by experienced researchers in your field

- rapid publication on acceptance

- support for research data, including large and complex data types

- gold Open Access which fosters wider collaboration and increased citations

- maximum visibility for your research: over $100 \mathrm{M}$ website views per year

At BMC, research is always in progress.

Learn more biomedcentral.com/submissions 